\title{
Status of soil chemical properties and nutrient contents of some crops cultivated of sahl el-tina north sinai under irrigation with low water quality of el-salam canal
}

\author{
S. E. M. El-Sisi \\ Soil, Water and Enviro. Res. Inst. (SWERI) - Agric. Res. C. (ARC), Giza- Egypt. \\ Corresponding author: s.elsisi@yahoo.com
}

\begin{abstract}
A survey study was carried out on soil chemical characteristics and nutrients content of crops at Sahl El-Tina (North Sinai), irrigated with El-Salam canal water. Soil samples were collected from 0-60 cm depth from ten sites. Soil $\mathrm{pH}$ values varied from 7.40 to 8.01 , EC of soil ranged from 1.93 to $7.28 \mathrm{dS} / \mathrm{m}$. Dominant soluble cation was $\mathrm{Na}^{+}$followed by $\mathrm{Ca}^{++}$then $\mathrm{Mg}^{++}$and $\mathrm{K}^{+}$. Dominant soluble anion was $\mathrm{Cl}$ - followed by $\mathrm{SO}_{4}{ }^{--}$then $\mathrm{HCO}_{3}{ }^{-}$, no $\mathrm{CO}_{3}{ }^{-}$was found in the last order. Ranges of soil available nutrients $(\mathrm{mg} / \mathrm{kg}$ ) were 6.84 to 66.82 for $\mathrm{N}, 1.73$ to 3.75 for $\mathrm{P}, 135.5$ to 164.00 for $\mathrm{K}, 1.01$ to 14.41 for Fe, 0.05 to 2.99 for $\mathrm{Mn}, 0.03$ to 1.61 for $\mathrm{Zn}$ and 0.98 to 5.29 for $\mathrm{Cu}$. Ranges for N P K in plant (\%) are 2.79 to 5.11 for N, 0.33 to 0.55 for P, and 1.87 to 4.92 for K. Ranges for Fe, Mn, Zn, Cu in plant (mg/kg) 37.83 to $75.24(\mathrm{Fe}), 25.14$ to $50.79(\mathrm{Mn}), 37.00$ to 57.79 $(\mathrm{Zn}) . \mathrm{Cu}$ was within the toxic level in all the tested crops, ranged from 36.57 to 78.25 .
\end{abstract}

Key words: Sahl El-Tina, El-Salam canal water, North Sinai , soil chemical.

\section{Introduction}

For many years, agriculture and socio-economic development in Sinai were always slow due to limited or scarce water resources. Therefore, the main strategy of socio- economic development of Egypt, since late years of the nineteen eighties was the re-use of agricultural drainage water after mixing it with Nile water. Hussein and Raouf (2002) stated that El-Salam canal would be fed with agricultural drainage water to cultivate large areas in northern Sinai.

Mostafa (2003) and Agram and Amer (2012) found that the EC of El-Salam Canal water varies from 1.30 to $2.12 \mathrm{dSm}^{-1}$. Shaban and Helmy (2006) reported that EC of El-Salam irrigation water ranged between 1.43 to $2.14 \mathrm{dS} / \mathrm{m}$. Ramadan and ElFayomy (2002) found increasing EC of soil resulted from the use of low water quality mixed with Nile water.

Hafiz (2001) revealed that the mean values of all available macronutrients, of $\mathrm{N}, \mathrm{P}$ and $\mathrm{K}$, increased in soil irrigated with low quality water. El-Sheikh (2003) showed that available $-\mathrm{N}$ and $\mathrm{P}$ were greater in soils which received mixed waters as compared with soils which received canal fresh water. ElKholy et al. (2000) studied the contents of Fe, Zn, $\mathrm{Mn}$ and $\mathrm{Cu}$ in soils irrigated low quality water and found that the contents of these elements increased compared with irrigation with Nile water; increases were 4 folds (Fe) and 20 folds ( $\mathrm{Zn})$.

Mostafa (2001a) reported that application of sewage water increased the P-concentration in seeds of broad beans. El-Banna et al. (2004) and Sallam et al. (2008) noticed a non-significant difference as a result of irrigation with Nile water or El-Serw drain water on $\mathrm{N} \%, \mathrm{P} \%$ and $\mathrm{K} \%$ of wheat straw, nevertheless irrigation with Nile water caused increases in the uptake of $\mathrm{N}, \mathrm{P}$ and $\mathrm{K}$ by wheat grains and straw.

Truby and Raba (1990) reported that irrigation with waste water caused enrichment of $\mathrm{Zn}$ in soil and led to increasing its uptake by strawberry and tomatoes. Mostafa (2001b) reported that Fe, $\mathrm{Zn}$ and Mn concentrations in seed of barley under irrigation with sewage water were greater than those irrigated with Nile water. Sallamy et al. (2008) showed that $\mathrm{Fe}, \mathrm{Zn}$ and $\mathrm{Mn}$ contents in wheat grains were highest for plant irrigated with Bahr El-Bakar drain water. Selem et al. (2000) collected samples of strawberry, tomatoes, eggplant peppers and squash cultivated at different soils at Sharkia Governorate. Data revealed that irrigation with waste water increased micronutrients contents $(\mathrm{Fe}, \mathrm{Zn}, \mathrm{Mn}$ and $\mathrm{Cu}$ ) in leaves and fruits of pants. Badawy et al. (2013) studied contamination with metals in plants in Sahl ElHessania area, Sharqiya irrigated from Bahr El-Baqar drain and El-Salam canal. The concentration of metals in the edible parts for eight plant species grown showed significant increases of Fe, Zn, Mn and $\mathrm{Cu}$ concentrations in plants irrigated with $\mathrm{Bahr}$ El-Bakr, as compared with those irrigated with ElSalam water.

The current work is a survey study on the effects of irrigation with this low water quality of El-Salam Canal on some chemical properties and the availability of nutrients of Sahl El-Tina soil at NorthSinai.

\section{Materials and Methods}

Sahl El-Tina is located in the south-west of Sinai, It is irrigated with El-Salam Canal (Table 1) the area is on Latitude $31^{\circ} \mathrm{N}$. and Longitude $33^{\circ} \mathrm{E}$. and its 
elevation about $23 \mathrm{~m}$. above the sea level. The land is above Lake Manzala and the water table depth varies between 1.12 to $2.20 \mathrm{~m}$.

Soil samples were chosen from ten villages to cover wide soil texture types of the studied area. Soil samples were collected from the depth of 0-60 cm. Then, air dried, crushed, sieved to pass a $2 \mathrm{~mm}$. and subjected to analysis. Samples of plants were also taken for analysis. Soil and plant analyses were done according to (Dewis and Fried, 1970), Chapman and Pratt (1961), Page et al. (1982), Jackson (1973) and Soltanpour (1985).

Table 1 to 3 show data about the samples Chapman and Pratt (1961). Available nutrients in soil were extracted by ammonium acetate $(1 \mathrm{M})$ for $\mathrm{K}$, sodium bicarbonate $(0.5 \mathrm{M})$ for $\mathrm{P}$ and $\mathrm{KCl}$ for $\mathrm{N}$.

Table 1. Chemical properties of El-Salam Canal irrigation water

\begin{tabular}{|c|c|c|c|c|c|c|c|c|c|}
\hline \multirow[t]{3}{*}{$\mathbf{p H}$} & \multirow[t]{3}{*}{$\mathbf{E C}$} & \multicolumn{8}{|c|}{ Chemical properties } \\
\hline & & \multicolumn{8}{|c|}{ Soluble ions } \\
\hline & & $\mathrm{CO}_{3}{ }^{--}$ & $\mathrm{HCO}_{3}{ }^{-}$ & $\mathrm{Cl}^{-}$ & $\mathrm{SO}_{4}=$ & $\mathrm{Na}^{+}$ & $\mathbf{K}^{++}$ & $\mathrm{Ca}^{++}$ & $\mathbf{M g}^{++}$ \\
\hline 7.6 & 2.41 & --- & 3.55 & 12.94 & 8.10 & 15.53 & 0.49 & 4.97 & 3.65 \\
\hline \multicolumn{10}{|c|}{ Elemental ions (mg/l) } \\
\hline \multicolumn{10}{|c|}{ Nutrients } \\
\hline \multicolumn{3}{|c|}{ Macro } & \multicolumn{7}{|c|}{ Micro } \\
\hline & & $\mathrm{P}$ & & e & & & $\mathrm{Zn}$ & & $\mathrm{Cu}$ \\
\hline & & 1.10 & & 91 & & & 0.78 & & 0.06 \\
\hline
\end{tabular}

Table 2. Sites of the studied soil samples at Sahl El-Tina district.

\begin{tabular}{|c|c|c|c|c|c|}
\hline \multicolumn{6}{|c|}{ Soil sample } \\
\hline No. & Sites & Texture & No. & Site & Texture \\
\hline 1 & Village No.1 & Sandy Loam & 6 & Village No.6 & Loamy \\
\hline 2 & Village No.2 & Clay Loam & 7 & Village No.7 & Clay \\
\hline 3 & Village No.3 & Clay & 8 & Gilbana Village & Sandy \\
\hline 4 & Village No.4 & Clay Loam & 9 & Village of Abdo Hamada & Clay \\
\hline 5 & Village No.1150 & Loamy Sand & 10 & Village of Hamdy El-Bayoumy & Loamy \\
\hline
\end{tabular}

Table3. Leave samples of cultivated crops irrigated from El-Salam Canal water.

\begin{tabular}{|c|c|c|c|}
\hline \multicolumn{3}{|c|}{ Leaves } & \multirow{2}{*}{$\begin{array}{l}\text { Scientific Latin name } \\
\text { (Reuter and Robinson, } \\
\text { 1986) \& (Martin et al., } \\
\text { 1976) }\end{array}$} \\
\hline Season & crop & Stage of collection & \\
\hline \multirow[t]{2}{*}{ Winter } & Alfalfa & $\begin{array}{l}\text { Whole Shoot before } \\
\text { flowering }\end{array}$ & Medicago sativa \\
\hline & $\begin{array}{l}\text { Faba (field) bean } \\
\text { Sugar Beat }\end{array}$ & $\begin{array}{l}\text { At pod formation } \\
\text { At tubers formation }\end{array}$ & $\begin{array}{l}\text { Vicia faba } \\
\text { Beta vulgaris }\end{array}$ \\
\hline \multirow[t]{2}{*}{ Summer } & $\begin{array}{l}\text { Corn (Maize) } \\
\text { Cotton }\end{array}$ & $\begin{array}{l}\text { At teaseling formation } \\
\text { At cotton almond } \\
\text { formation }\end{array}$ & $\begin{array}{l}\text { Zea mays } \\
\text { Gossypium hirsutum }\end{array}$ \\
\hline & Tomato & At fruits formation & $\begin{array}{l}\text { Lycopresicon } \\
\text { esculentiun }\end{array}$ \\
\hline
\end{tabular}

\section{Results and Discussion}

\section{Soil chemical characteristics:}

Soil chemical characteristics are shown in Table 4 and Figures 1 to 4

\section{Soil pH}

Data of soil $\mathrm{pH}$ show that the $\mathrm{pH}$ varied from 7.40 to 8.01 , which indicat that soils are slightly to moderately alkaline. Data also, show that $\mathrm{pH}$ of sites of $1,3,4,6$ and 9 is slightly alkaline $(7.40<$ soil $\mathrm{pH}<7.87$ ), and in sites 2, 5, 7, 8 and 10 it is moderately alkaline $\mathrm{pH}(7.90<$ soil $\mathrm{pH}<8.01)$.
Soils irrigated with good quality Nile water had $\mathrm{pH}$ around 7.0 (Wahdan, 2009).

\section{Soil EC}

Generally it can be noticed from the values of soil EC (Table 4 and Figure 2), ranged from 1.93 to 7.28 $\mathrm{dS} / \mathrm{m}$. According to soil salinity classification (Table 5) soils at Sahl El-Tina are saline.

Salinity development is due to continuous irrigation with this low water quality. Wahdan (2009) reported that EC $\mathrm{dS} / \mathrm{m}$ of soils irrigated with Nile water rang of 1.0 to 2.5 . Ramadan and ElFayomy (2002) reported similar findings in their research. 
Soluble ions of soil

Values of soluble cations $\mathrm{Ca}^{++}, \mathrm{Mg}^{++}, \mathrm{Na}^{+}$and $\mathrm{K}^{+}$ (mmole/L) as well as soluble anions of $\mathrm{HCO}_{3}^{--}, \mathrm{Cl}^{-}$ and $\mathrm{SO}_{4}^{--}$are presented in Table 4.

\section{Cations:}

Data show that, the dominant cation was $\mathrm{Na}+$ followed by $\mathrm{Ca}^{++}$and then $\mathrm{Mg}^{++}$, while $\mathrm{K}^{+}$was the least. Their ranges were 5.43to $24.78 \mathrm{me} / 1$ for $\mathrm{Ca}^{++}$, 3.29 to $22.98 \mathrm{mmole} / \mathrm{L}$ for $\mathrm{Mg}^{++}$, 8.60 to 46.77 mmole/L for $\mathrm{Na}^{+}, 0.88$ to 4.04 mmole/L for K .

Wahdan , (2009) stated that soil irrigated with water of River Nile contained soluble cations with mean values of $3.62,3.25,4.84$ and 0.19 mmole/ $/ \mathrm{L}$ for $\mathrm{Ca}^{++}, \mathrm{Mg}^{++}, \mathrm{Na}^{+}$, and $\mathrm{K}^{+}$, respectively. Therefore, water of El- Salam canal caused an increase in soluble catinos of soil from 1.5 to 6.8 folds for $\mathrm{Ca}^{++}$, from 1.0 to 7.1 folds for $\mathrm{Mg}^{++}$, from 1.8 to 10 folds for $\mathrm{Na}^{+}$and from 4.6 to 21.3 folds for
$\mathrm{K}^{+}$. These trends agree with the findings of Hafiz (2001) and El-Sheikh (2000).

\section{Anions:}

Data show that, the dominant anion was $\mathrm{Cl}^{-}$ followed by $\mathrm{SO}_{4}^{--}$then $\mathrm{HCO}_{3}^{-}$with no $\mathrm{CO}_{3}^{-}$. Their general ranges mmole/L were 1.10 to 1.67 for $\mathrm{HCO}_{3}^{--}, 9.30$ to 44.66 for $\mathrm{Cl}^{-}$and 8.16 to 41.21 for $\mathrm{SO}_{4}^{--}$.

Selem et al.(2000), stated that soil irrigated with the water of River Nile contained soluble anions with mean values (mmole/L) of 2.05, 1.93 and 1.00 for $\mathrm{Cl}^{-}$ , $\mathrm{SO}_{4}^{-}{ }^{-}$and $\mathrm{HCO}_{3}^{-}$, respectively. Therefore, ElSalam caused increases of soluble anions of 4.50 to 21.8-folds for $\mathrm{Cl}^{-}$and 4.2 to 21.4 -folds for $\mathrm{SO}_{4}^{--}$and 1.1 to 1.7 -folds for $\mathrm{HCO}_{3}^{-}$relative to the corresponding values of anions soils irrigated with the River Nile. These results agree with those of Zein et al (2002).

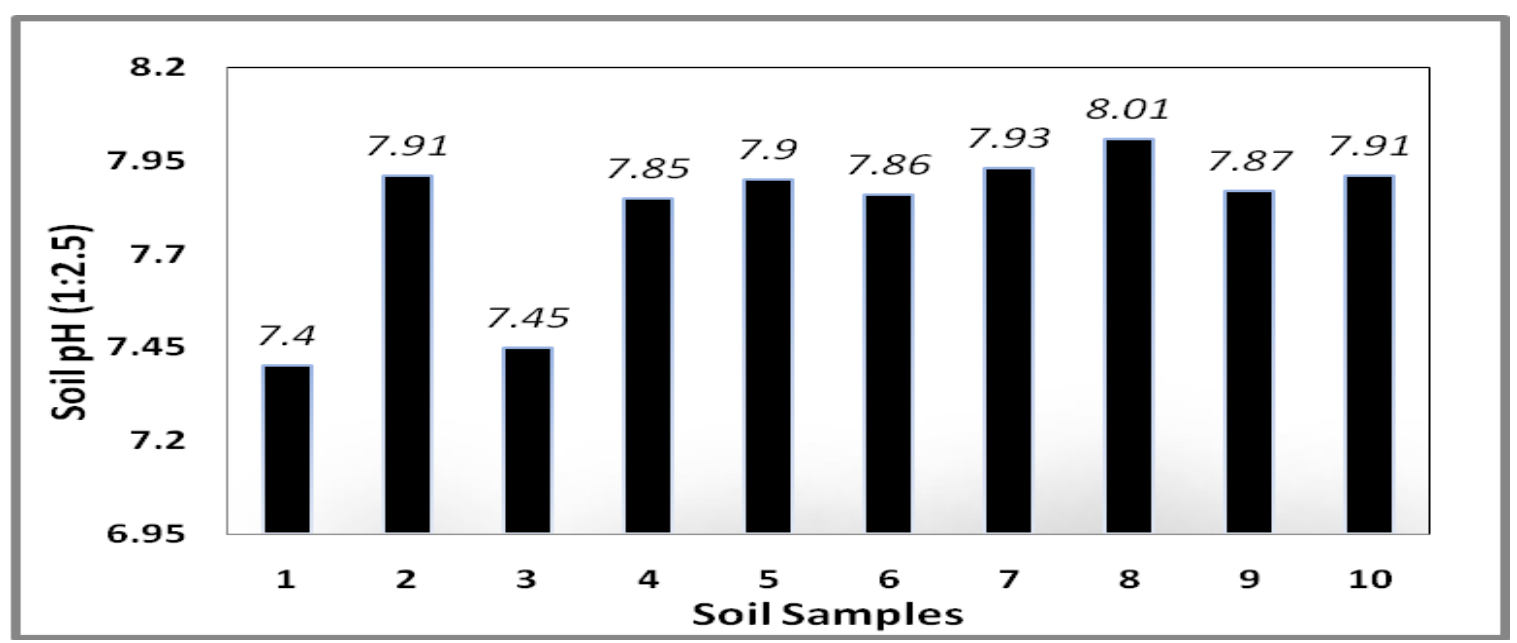

Fig (1): pH of different soil sites at Sahl El-Tina district irrigated with low water quality of El-Salam Canal.

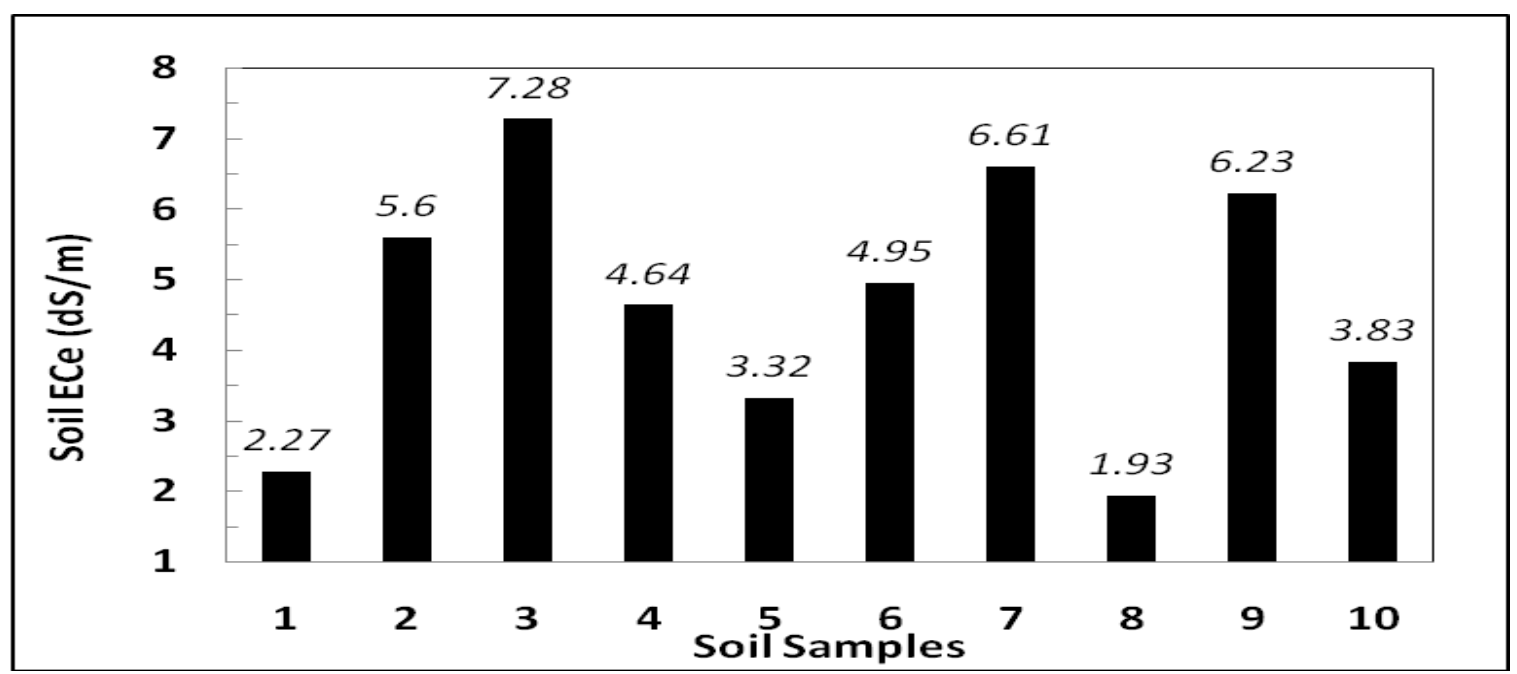

Fig (2): EC (dS/m) of different soil sites at Sahl El-Tina district irrigated with low water quality of El-Salam Canal. 
Table 4. Status of some chemical properties and available of some elemental ions of soil at Sahl ElTina district irrigated with low water quality of El-Salam Canal.

\begin{tabular}{|c|c|c|c|c|c|c|c|c|c|c|}
\hline \multirow{4}{*}{$\begin{array}{l}\text { Soil } \\
\text { sample } \\
\text { No }\end{array}$} & \multicolumn{10}{|c|}{ Chemical properties } \\
\hline & \multirow{3}{*}{ 플 $\stackrel{ }{\ddot{\Xi}}$} & \multirow{3}{*}{ 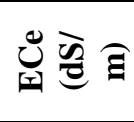 } & \multicolumn{8}{|c|}{ Soluble Ions of soil paste (me/l) } \\
\hline & & & \multicolumn{4}{|c|}{ Cations } & \multicolumn{4}{|c|}{ Anions } \\
\hline & & & $\mathbf{C a}^{++}$ & $\mathbf{M g}^{++}$ & $\mathrm{Na}^{+}$ & $\mathbf{K}+$ & $\mathrm{CO}_{3}=-$ & $\mathrm{HCO}_{3}^{-}$ & $\mathrm{Cl}^{-}$ & $\mathrm{SO}_{4}^{--}$ \\
\hline 1 & 7.40 & 2.27 & 5.74 & 3.29 & 11.42 & 2.15 & - & 1.26 & 12.20 & 8.16 \\
\hline 2 & 7.91 & 5.60 & 19.96 & 9.31 & 22.18 & 3.32 & - & 1.63 & 34.18 & 26.44 \\
\hline 3 & 7.45 & 7.28 & 23.22 & 22.98 & 28.61 & 3.75 & - & 1.10 & 41.25 & 41.21 \\
\hline 4 & 7.85 & 4.64 & 12.35 & 14.48 & 21.39 & 3.00 & - & 1.53 & 24.10 & 22.50 \\
\hline 5 & 7.90 & 3.32 & 6.30 & 3.65 & 22.76 & 1.86 & - & 1.38 & 23.59 & 9.53 \\
\hline 6 & 7.86 & 4.95 & 12.28 & 11.19 & 25.72 & 1.88 & - & 1.60 & 29.20 & 21.06 \\
\hline 7 & 7.93 & 6.61 & 24.78 & 17.80 & 30.80 & 4.04 & - & 1.64 & 37.46 & 33.06 \\
\hline 8 & 8.01 & 1.93 & 5.43 & 4.59 & 8.60 & 0.88 & - & 1.67 & 9.30 & 8.60 \\
\hline 9 & 7.87 & 6.23 & 11.08 & 10.00 & 46.77 & 1.73 & - & 1.48 & 44.66 & 18.69 \\
\hline 10 & 7.91 & 3.83 & 7.86 & 4.27 & 25.68 & 1.19 & - & 1.42 & 26.9 & 10.68 \\
\hline \multirow{4}{*}{$\begin{array}{l}\text { Soil } \\
\text { sample No }\end{array}$} & \multicolumn{10}{|c|}{ Available of elemental Ions (mg/kg. soil) } \\
\hline & \multicolumn{10}{|c|}{ Nutrients Ions } \\
\hline & \multicolumn{5}{|c|}{ Macro-nutrients } & \multirow{2}{*}{\multicolumn{4}{|c|}{ Micro-nutrients }} & \\
\hline & $\mathbf{N}$ & & $\mathbf{P}$ & $\mathbf{K}$ & & & & & & $\mathbf{C u}$ \\
\hline 1 & 7.86 & & 3.59 & 144. & & 6.83 & 1.17 & 1.4 & & 5.29 \\
\hline 2 & 6.84 & & 2.70 & 164. & & 13.43 & 2.33 & 1.0 & & 1.07 \\
\hline 3 & 7.76 & & 3.00 & 151. & & 8.25 & 1.09 & 1.6 & & 3.66 \\
\hline 4 & 27.45 & & 2.76 & 140. & & 9.40 & 1.84 & 1.0 & & 4.74 \\
\hline 5 & 32.51 & & 3.55 & 135. & & 12.34 & 1.95 & 0.6 & & 1.08 \\
\hline 6 & 42.23 & & 2.70 & 141. & & 11.55 & 1.42 & 0.8 & & 1.16 \\
\hline 7 & 36.65 & & 3.58 & 143. & & 9.38 & 1.79 & 0.7 & & 4.26 \\
\hline 8 & 60.40 & & 2.26 & 139. & & 14.41 & 2.99 & 1.3 & & 0.98 \\
\hline 9 & 41.55 & & 1.73 & 143. & & 1.93 & 0.79 & 0.3 & & 4.55 \\
\hline 10 & 66.83 & & 3.75 & 139. & & 1.01 & 0.05 & 0.0 & & 1.34 \\
\hline
\end{tabular}

Table 5. Ranges of salinity of the studied soils at Sahl El-Tina area and their classification according to FAO/UNESO, 1973.

\begin{tabular}{clcc}
\hline \multicolumn{2}{c}{$\begin{array}{c}\text { Soil ECe }(\mathrm{ds} / \mathrm{m}) \text { classes as } \\
(\text { FAO/ UNESCO, 1973) }\end{array}$} & soil sites & Effects on growing crops \\
\hline EC $<\mathbf{2 . 0}$ & Salt Free & $\mathbf{8}$ & $\begin{array}{c}\text { Salinity effects are mostly negligible. } \\
\text { Salinity effects are mostly negligible } \\
\text { except for the most sensitive plants. }\end{array}$ \\
\hline $\mathbf{2 . 0}<$ EC $<\mathbf{4 . 0}$ & Slightly Saline & $\mathbf{1 - 5 - 1 0}$ & Yields of many crops restricted. \\
\hline 4.0 $<$ EC $<\mathbf{8 . 0}$ & Moderately Saline & $\mathbf{2 - 3 - 4 - 6 - 7 - 9}$ & .
\end{tabular}

\section{Available macro-nutrients of soil}

Values of available macro-nutrients of $\mathrm{N}, \mathrm{P}$ and $\mathrm{K}(\mathrm{mg} / \mathrm{kg}$. soil) are presented in Table 4 and Fig3.

Available N:

Avail.-N mg/kg recorded low levels in soils 1 to 3 with values of 6.84 to 7.86 . In the other sites, the values were high, ranging from 27.45 to 66.83 . These variations can be due agriculture activities in soils of 4 to 10 (Azam et al., 1990).

Available P:

The values of available $-\mathrm{P}$ in sites of 2, 4, 6, 8 and 9 are $<3 \mathrm{mg} / \mathrm{kg}$. Values in the other sites are between 3.55 to 3.75. According to Soltanpoor (1985) soil of $<3 \mathrm{mg} / \mathrm{P} / \mathrm{kg}$ are classified as low-P while those of 39 are medium P-soils. Low available $-\mathrm{N}$ and available-P soils can be supplemented with organic manures rich in $\mathrm{N}$ and $\mathrm{P}$ as well as $\mathrm{N}$ and $\mathrm{P}$ fertilizers.

\section{Available K:}

Soils had values of available-K rang from 135.5 to $164 \mathrm{mg} / \mathrm{kg}$. Soltanpour (1985), considered 120 $\mathrm{mg} / \mathrm{kg}$ available $\mathrm{K}$ as high.

Wahdan (2009) reported that soils irrigated with the good quality Nile water, 24 to $32 \mathrm{mg} / \mathrm{kg}$ available $\mathrm{N}, 3$ to $9 \mathrm{mg} / \mathrm{kg}$ available $\mathrm{P}$ and 125 to $142 \mathrm{mg} / \mathrm{kg}$ available $\mathrm{K}$. In the current study, ranges of available $\mathrm{N}, \mathrm{P}$ and $\mathrm{K}(\mathrm{mg} / \mathrm{kg})$ were $6.84-66.83,1.73-3.75$ and 135.5-164.0.

Available micro-nutrients of soil

Values of available micro-nutrients of $\mathrm{Fe}, \mathrm{Mn}$, $\mathrm{Zn}$ and $\mathrm{Cu}$ are presented in Table 4 and Figure 4.

Available Fe:

Most soils except soil of sites 9 and 10 had high of available-Fe (> $5 \mathrm{mg} \mathrm{Fe} / \mathrm{kg}$ ) which is considered high according to Soltanpour, (1985). Shaban (1998) and El-Sheikh (2000, recorded available-Fe 
of 0.14 to 3.51 in soils irrigated with good quality Nile water.

Available Mn:

Except soil of site 10, the majority of the tested soils had values of available - Mn ranging from 0.79 to $2.99 \mathrm{mg} / \mathrm{kg}$ and therefore they had high availableMn > $1.0 \mathrm{mg}$. $/ \mathrm{kg}$.soil, (Soltanpour 1985). Shaban (1998) and El-Sheikh (2000), recorded availableMn were of 0.08 to $1.48 \mathrm{mg} / \mathrm{kg}$ in soils irrigated with Nile water. Thus El- Salam Canal water caused high available-Mn in Sahl El-Tina soils. These results agree with those obtained by El-Kholy et al. (2000). Available - Zn.
Regarding the status of available $-\mathrm{Zn}$ of the tested soils, the sites of 5,6,7,9 and 10 had values of available $-\mathrm{Zn}$ of 0.03 to $0.84 \mathrm{mg} / \mathrm{kg}$. They would be low in available - Zn (Soltanpour 1985). The soils of sites 1, 2, 3, 4 and 8 had values of available- $\mathrm{Zn}$ of 1.03 to $1.61 \mathrm{mg} / \mathrm{kg}$. Thus, they fall within medium to high in available $\mathrm{Zn}$ (Soltanpour 1985). Shaban (1998), El-Sheikh (2000) and Farragallah and Essia (2005), reported that soils irrigated with good quality Nile water recoded available-Zn 0.03 to 0.60 $\mathrm{mg} / \mathrm{kg}$. El- Salam Canal water must had increased available-Zn of Sahl El-Tina soils. These results agree with findings of El-Kholy et al. (2000).

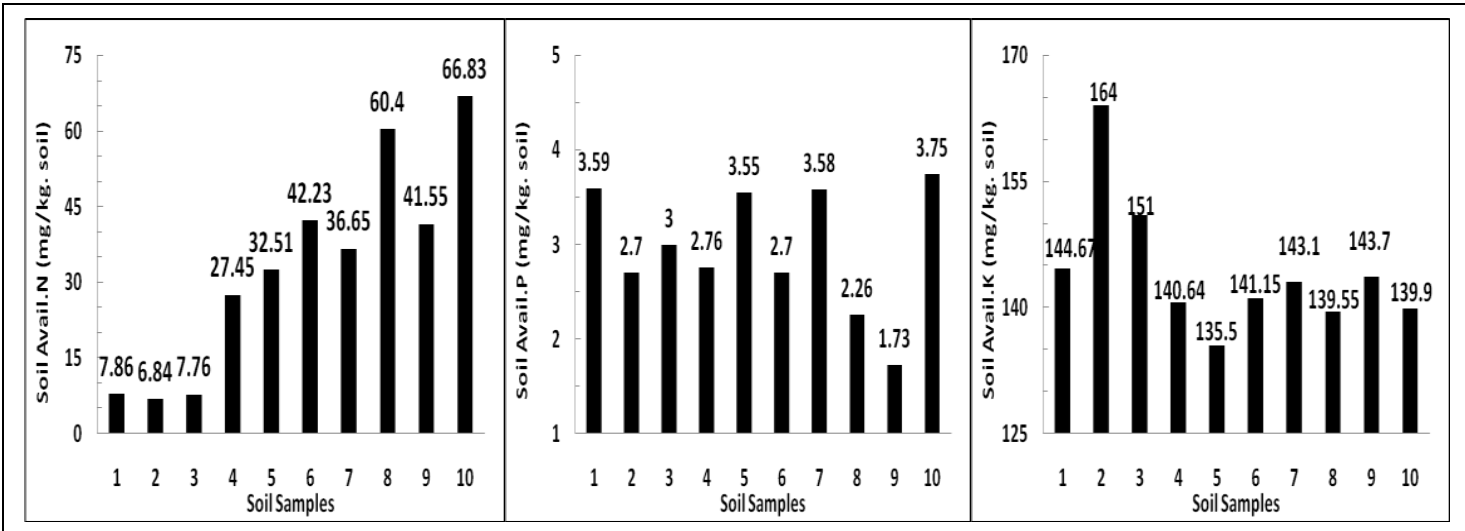

Fig (3): Avail-N, P and K of different soil sites at Sahl El-Tina area irrigated with low water quality of El-Salam Canal.

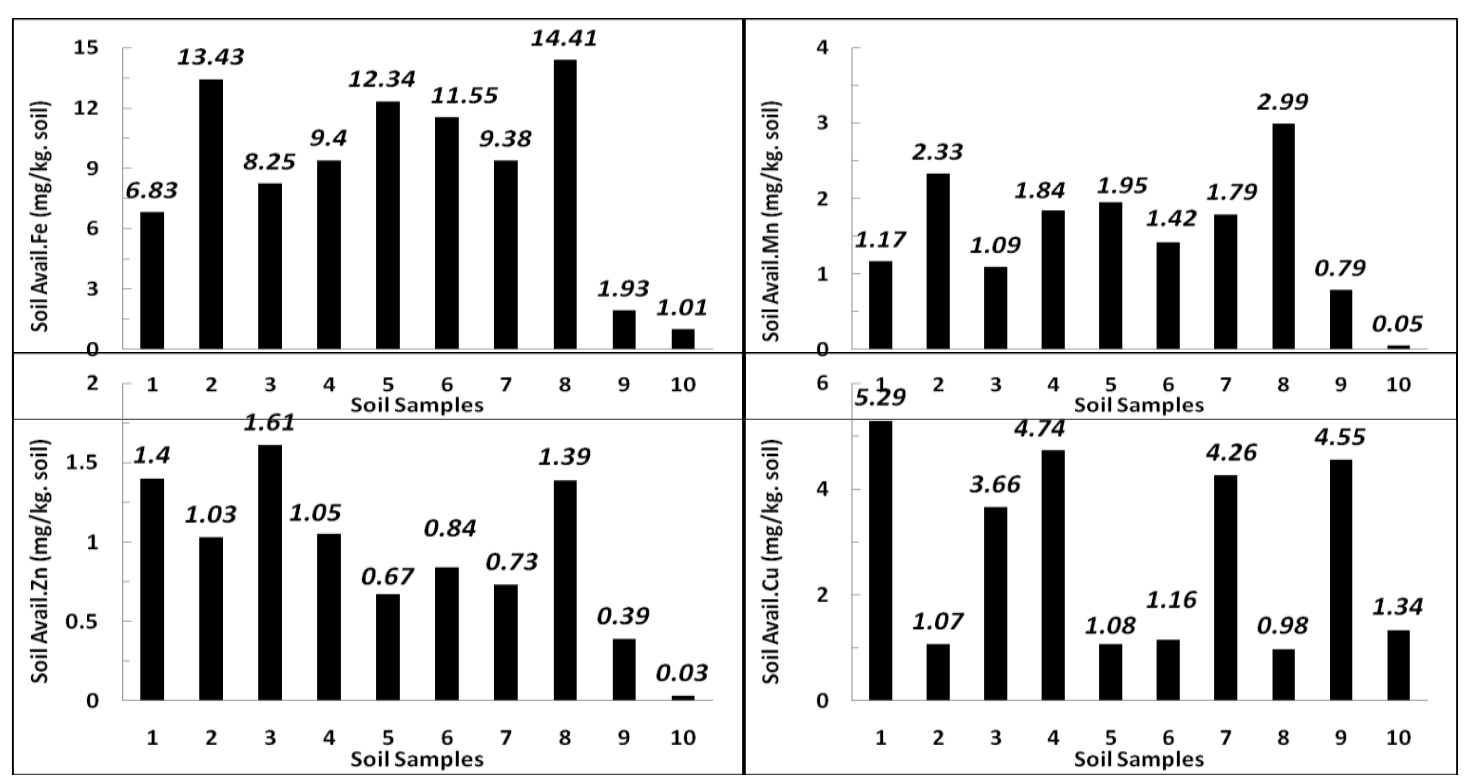

Fig (4): Avail-Fe, Mn, $\mathrm{Zn}$ and $\mathrm{Cu}$ of different soil sites at Sahl El-Tina area irrigated with low water quality of ElSalam Canal. 
Table 6. Nutrient contents in leaves of some crop of sites at Sahl El-Tina (Averages).

\begin{tabular}{|c|c|c|c|c|c|c|c|}
\hline \multirow{3}{*}{ Crops } & \multicolumn{7}{|c|}{ Nutrients in dry matter } \\
\hline & \multicolumn{3}{|c|}{ Macro (\%) } & \multicolumn{4}{|c|}{ Micro (mg./kg.dry wt.) } \\
\hline & $\mathbf{N}$ & $\mathbf{P}$ & $\mathbf{K}$ & $\mathbf{F e}$ & Mn & Zn & $\mathbf{C u}$ \\
\hline Alfalfa & 2.79 & 0.39 & 1.87 & 63.96 & 45.30 & 57.79 & 37.72 \\
\hline Faba bean & 2.78 & 0.33 & 2.27 & 37.83 & 50.79 & 43.97 & 38.24 \\
\hline Sugar Beat & 4.60 & 0.44 & 4.51 & 59.77 & 36.88 & 53.27 & 36.57 \\
\hline Maize & 2.99 & 0.39 & 3.02 & 57.79 & 27.96 & 37.00 & 39.72 \\
\hline Cotton & 3.48 & 0.42 & 4.23 & 59.86 & 47.99 & 49.54 & 41.11 \\
\hline Tomato & 5.11 & 0.55 & 4.92 & 75.24 & 25.14 & 48.65 & 78.25 \\
\hline
\end{tabular}

Available - Cu.

Values of available- Cu ranged from 0.98 to 5.29 $\mathrm{mg} / \mathrm{kg}$. Therefore all the soils of the investigated sites showed high levels of available $-\mathrm{Cu}$, i.e. $>0.5 \mathrm{mg}$. $/ \mathrm{kg}$ (Soltanpour 1985). Shaban (1998), El-Sheikh (2000) and Farragallah and Essia (2005), stated that soils irrigated with good quality Nile water contained 0.02 to $0.09 \mathrm{mg} / \mathrm{kg}$. Irrigation of Sahl ElTina soils with El- Salam Canal water must lead increased available - $\mathrm{Cu}$ and may toxic levels in some sites. These trends are in agreement with the findings of El-Kholy et al. (2000) and Selem et al. (2000).

\section{Nutrients content of some cultivated crops:}

Nutrient contents of leaves of some growing crops at the studied sites of Sahl El-Tina area under conditions of irrigation with low water quality of El Salam Canal are shown in Table 6 and in Figures 5 and 6.

\section{Contents of $\mathbf{N}, \mathbf{P}$ and $\mathrm{K}$ in crops.}

Contents of $\mathrm{N}, \mathrm{P}$ and $\mathrm{K}$ of the different tested crops, were tabulated in Table 6 and illustrated in Fig.(5). The results showed that contents of $\mathrm{N}$ ranged from $2.78 \%$ to $5.11 \%$ and ranged from $0.33 \%$ to $0.55 \% \mathrm{P}$ and those of $\mathrm{K} 1.87 \%$ to $4.92 \%$.

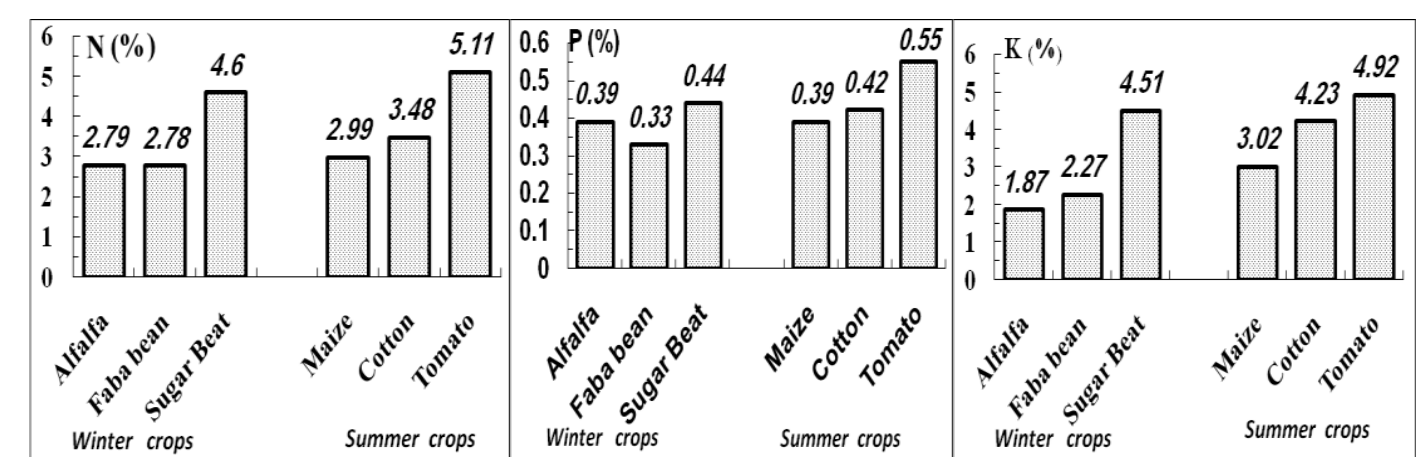

Fig (5): N, P and K (\%) of some cultivated crops.

The crops can be arranged according to their $\mathrm{N}$ or $\mathrm{P}$ in the descending order of Tomato $>$ Sugar beet $>$ Cotton $>$ Maize > Alfalfa > Faba bean. As for $\mathrm{K}$ the order were similar to that of $\mathrm{N}$ and $\mathrm{K}$ except that bean > alfalfa. According Leo and James (1973) and Reuter and Robinson (1986), all tested crops contained N, P and $\mathrm{K}$ within the adequate ranges for the mentioned crops, except $\mathrm{N}$ of Alfalfa and bean which showed a marginal ranges.

Contents of $\mathrm{Fe}, \mathrm{Mn}, \mathrm{Zn}$ and $\mathrm{Cu}$ in crops.

Contents of $\mathrm{Fe}, \mathrm{Mn}, \mathrm{Zn}$ and $\mathrm{Cu}$ of crops are shown in Table 6 and illustrated in Figures 6. Contents $(\mathrm{mg} / \mathrm{kg})$ ranged from 37.83 to 75.24 $\mathrm{mg} / \mathrm{kg}$ for $\mathrm{Fe}, 25.14$ to $50.79 \mathrm{mg} / \mathrm{kg}$ for $\mathrm{Mn}, 37.00$ to $57.79 \mathrm{mg} / \mathrm{kg}$ for $\mathrm{Zn}$ and 36.57 to $78.25 \mathrm{mg} / \mathrm{kg}$ for $\mathrm{Cu}$.

According to classification described by Reuter and Robinson (1986), Iwai et al. (1972), Leo and James (973) jones (1975), Mengel and kirkby
(1978), it can be concluded that micronutrients in those crops as follows:

Alfalfa adequate for all nutrients. Faba bean: low $\mathrm{Fe}$ and adequate $\mathrm{Mn}$ and $\mathrm{Zn}$, but marginal $\mathrm{Cu}$. For sugar beet $\mathrm{Fe}$ is and adequate for $\mathrm{Mn}$ and $\mathrm{Zn}$, Maize and Cotton recorded adequate for $\mathrm{Fe}, \mathrm{Mn}$ and $\mathrm{Zn}$, Tomato showed low $\mathrm{Fe}$ and $\mathrm{Mn}$ and adequate for $\mathrm{Zn}$.

It could be concluded what alfalfa had adequate content of Fe, Mn and Zn. Faba bean showed low $\mathrm{Fe}$ and adequate $\mathrm{Mn}$ and $\mathrm{Zn}$. Sugar beat showed adequate $\mathrm{Mn}$ and $\mathrm{Zn}$. Maize and Cotton had adequate contents from all of $\mathrm{Fe}, \mathrm{Mn}$ and $\mathrm{Zn}$. Tomato were low in $\mathrm{Fe}$ and $\mathrm{Mn}$ and adequate $\mathrm{Zn}$. Kobata-Pendias and Pendias (1984) and Misra and Mena (1991), reported that $\mathrm{Cu}$ ranges from 4 to $15 \mathrm{mg} / \mathrm{kg}$, while Podlesakova et al. (2002) stated that $10 \mathrm{mg} / \mathrm{kg}$ of $\mathrm{Cu}$ in plants is critical. On the other hand, Iwai et al. (1975) showed that of $20.0 \mathrm{mg} / \mathrm{kg}$ is toxic. Thus $\mathrm{Cu}$ values in alfalfa, bean, maize, cotton and tomatoes are toxic. 


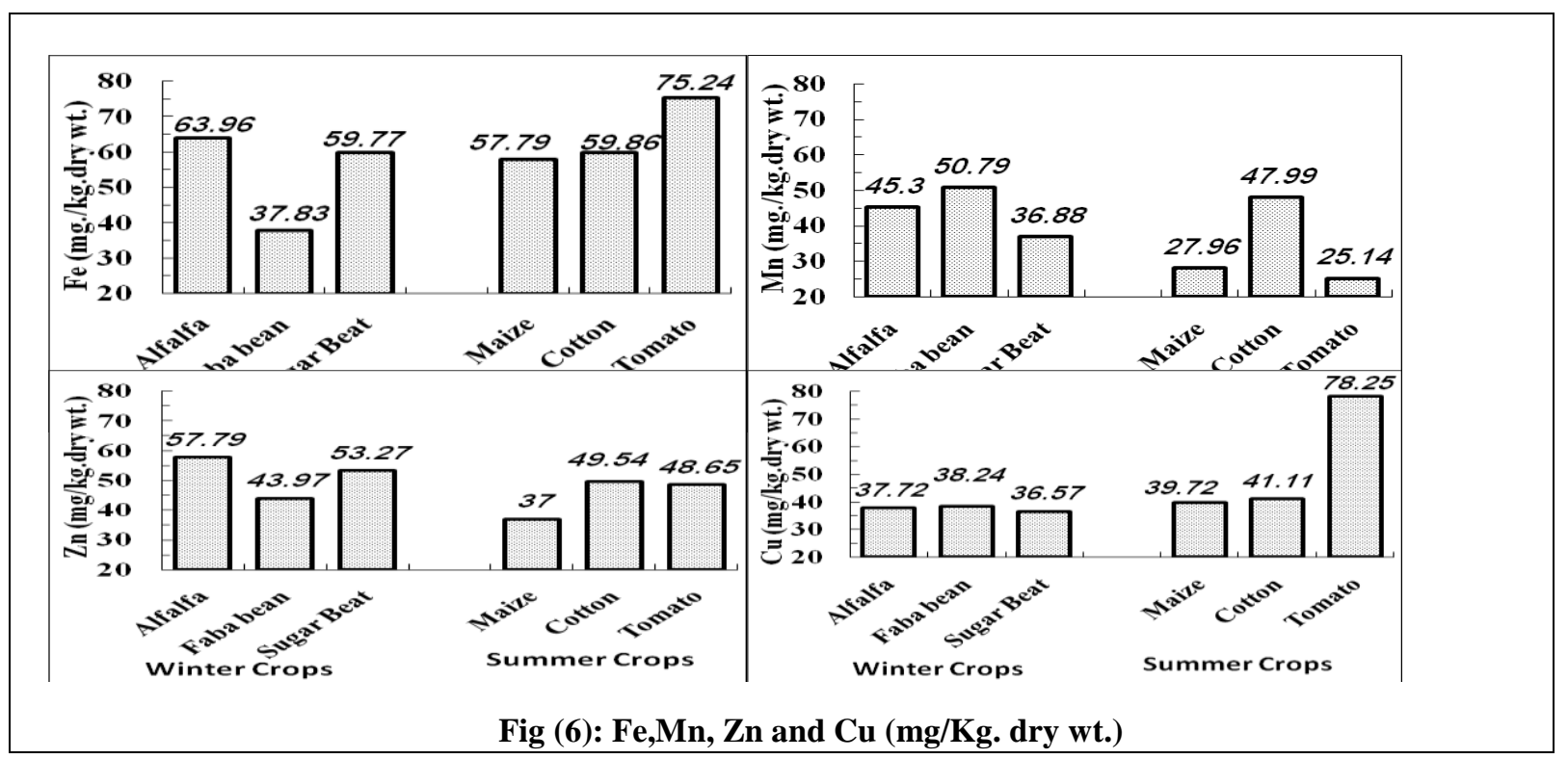

\section{References}

Agrama A. A and Amer A. S (2012): Investigation of El-Salam canal water quality, South ElQuantara area. J. of App. Sci. Res., 8 (4): $1927-$ 1935. Egypt.

Azam , F. M., Ashraf, A. L. and Sajjad, M. I. ( 1990) : Availability of soil and fertilizer nitrogen to wheat following rice - straw amendment .Biology and Fertility of Soils. 10: 134-138.

Badawy, R. K., Amr. M. A. G. and Hanan E. O. (2013): Health risks assessment of heavy metals and microbial contamination in water, soil and agricultural foodstuff from wastewater irrigation at Sahl El-Hessania area, Egypt. J. of App. Sci. Res. 9(4): 3091-3107.

Chapman, H. D. and Pratt., P. E. (1961): Methods for analysis of soils, plants and waters. Univ. of Calif, Div. of Agric. Sci. Cal. USA.

Dewis, J. and Fried, F. (1970) : Physical and chemical methods of soil \& water analysis. FAO organization of UN, Rome, Italy.

El-Banna, I. M. M., Abou El-defan, T. A., Selem, M. M. I. and El-Maghraby, T. A. (2004): Potassium fertilization and soil amendments interactions and their effects on wheat irrigated with different water qualities. J. Agric. Sci. Mansoura Univ. 29(10): 5953-5963.

El-Kholy, H. M., Abou El-defan, T. A., AbdAllah, A. E. and Kandil , N .F. (2000) : Environmental impact of irrigation with waste water Effluent on some soil properties. J. Agric. Sci. Mansoura Univ. 25(9): 5955-5962.

El-Sheikh, O. M. (2000): Effect of quality of irrigation waters on the absorption of some elements. M.Sc., Thesis Fac of Agric. Zagazige Univ., Egypt.

El-Sheike, O. M. (2003): Salinity problems of soils irrigated with water of low qualities. Ph.D. Thesis Faculty of Agric. Zagazig Univ., Egypt.

FAO/ UNESCO, (1973): "Irrigation drainage water and salinity" An International Source Book, IUNESCO. Hutchinson, London, UK.

Hafiz, W. A. (2001): Effect of drainage water on some Egyption soils and plant. M.Sc. Thesis, Fac. of Agric. Moshtohor, ZagazigUniv Egypt

Hussein, I. and Raouf, O. A. (2002): Water Issue in Egypt: Resources, pollution and protection endeavors. CEJOEM 8 (1): 3-21.

Iwai, I., Hadra and Sand, Y. (1975): Factors affecting cadmium uptake by the corn plant .Soil Sci. Plant Nutr.(Tokyo), 21: 37-46.

Jackson, M. L. (1973): Soil chemical analysis, Prentice Hall Inc., Englewood Cliffs, U.S.A.

Jones, J. B. (1975): Plant tissue analysis for micronutrients In : Micronutrients in agriculture . Eds: J.J.Mortvedt , P.M . Giordano and W.L. Lindsay, Soil Sci. Am. Inc. madison, Wisconsin.

Kobata-Pendias, A. and Pendias, H. (1984): Trace elements in soils and plants. CRC Inc. Boca Raton. Florida, USA.

Leo, M. W. and James, D. B. (1973): Soil testing and plant analysis. Soil Sci.Soc. of Amer. Inc., Madison, Wisconin, USA.

Mengal, K. and Kirkby, E. A. (1978) : Principles of plant nutrition . Inter.Potach Instit. Worblanfen, Bern., Switzerland.

Misra, S. G. and Mani, D. (1991): Soil pollution. Ashish Publishing House,Punjabi Bagh

Mostafa, M. M. (2001a): Nutrition and productivity of broad bean plant as affected by quality and 
source of irrigation water. Zagazeg. J. Agric. Res, 28 (3): 517 - 532.

Mostafa, M. M. (2001b): Nutrients uptake and dry matter yield of barley as affected by salinity of irrigation water and addition of organic material .Zagazeg .J. Agric., Res. (3) : 122- 129.

Mostafa, M. H. (2003): Effect of irrigation number, F. Y. $\mathrm{M}$ and $\mathrm{N}$ application rates on some properties of salt affected soil and wheat yield. Egypt.J. Appl. Sci, 18(3):401-411.

Page A. L., Miller, R. H. and Keeney D. R. (1982): Methods of soil analysis 11- Chemical and microbiological properties. Soil Sci. Soc. Amer. Madison Wisconsin, U.S.A.

Podlesakova, E., Nemecek, J. and Vacha, R. (2002): Critical values of trace elements in soils from the viewpoint of the transfer pathway soilplant. ROSTLINNA VYROBA , 48 (5) : 193202.

Ramadan, H. M and El-Fayomy M. E (2002): Spatial and temporal soil variability under the safe use of low quality water for irrigation at Bur El-Arab Area. Egypt J. Soil Sci; 42(1): 17-41.

Reuter, D. J. and Robinson J.B. (1986) : Plant analyses . An interpretation manual. Inktata Press. Melbourn, Sydeny, Australia.

Sallam, A. M., Khaled, A. and Soluman, M. A. M. (2008): Effect of irrigation water sources on productivity and grain quality of wheat. Third Environ. Conference, Fac. of Sci., Zagazig Univ., $59-75$
Selem, M. M., El-Kholy, H.M.; Abdel-Aziz, S. M. and Abou El-defan,Abdel-Aziz, S. M. (2000): Heavy metal contents of some vegetables irrigated with sewage effluent. Fayoum J.Agric. Res.\&Dev. 14(2) : 91-98.

Shaban, K. A.H (1998): Studies on pollution of some cultivated soils. M.Sc. Thesis, Fac. Of Agric; Zagazige Univ., Egypt

Shaban, K. A. and A. M. Helmy (2006): "Response of wheat to mineral and bio-fertilization under saline conditions. Zagazig.J. Agric. Res., 33(6): 1189-1205

Soltanpour, P. N. (1985): Use of $\mathrm{NH}_{4} \mathrm{HCO}_{3}-\mathrm{DTPA}$ soil test to evaluate elemental availability and toxicity. Commun. in Soil Sci. and Plant Analysis. 13 (3) 323-338.

Truby, P. and Raba, A. (1990): Heavy metal uptake by garden plants from Freeburg sewage farm waste water. Agri-biological Res. 43 (2): 139146.

Wahdan, M. E. (2009): Impact of water quality on soil environment and grown plants in east Nile Delta. PhD Thesis. Inst. Envir .Studies .Ain Shams Univ., Egypt.

Zein, F. I, El-Yammani, M. S., El-Leithy, A. A., and Moustafa, A. T. A. (2002): Effect of polluted irrigation water on some crops and their contents of heavy metal.2. Sugar Beet, Egypt.J. Soil Sci, 42 (2): 307-318. 
حالة بعض الخصائص الكيميائية للترية ومحتوى العناصر الغذائية لبعض المحاصيل المنزرعه في منطقة سهل الطينه (شمال سيناء) والخاضعة للرى بمياه ترعة السلام المنخفضة الجوده

$$
\begin{aligned}
& \text { صلاح الدين محمد السيسى } \\
& \text { معهد بحوث الأراضى والمياهوالبيئة- مركز البحوث الزراعية (مصر - الجيزة) }
\end{aligned}
$$

يهدف هذا البحث إلى حصر بعض التغييرات النوعية لبعض الخصائص الكيميائية للتربة ومحتوى العنلصر المغذية لبعض المحاصيل المنزروعة في منطقة سهل الطينه (شمال سيناء)، نتيجة خضوعها للري بمياه منخفضة الجوده من ترعة السلام0ولتحقيق الهدف من هذا البحث، تم جمع عينات مختلفة من التربة من عمق صفر - 60 سم من عشر قرى. وقد تم تحليل بعض الخصائص الكيميائية للتربة ومحتواها من المغذيات الميسرة فى عينات التربة التي تم جمعها0 مون من ناحية أخرى ومن نفس مواقع الدراسة ، نم أخذ عينات من اوراق بعض المض المحاصيل المختلفة عند إكتمال مرحلة النمو الخضري، ، لتحديد محتوياتها من المواد الغذائية المختلفة.

\section{أما بالنسبة للخصائص الكيميائية للتربة :}

فقد ترواحت قيم الـ pH للأراضى تحت الدراسة من 7,4 إلى الى 8,01 مما يعنى أن درجة حموضتها نتراوح من خفيفة إلى متوسطة القلوية ، كما ترواحت قيم الـ EC لها من 1.39 إلى 7,28 ديسيمنز/ م وهى تزيد عن تللك ملوحة تلك النوعية من الأراضى المروية بمياه النيل جيدة النوعية

كما أظهرت النتائج أن ايونات الصوديوم هى أكثر الكاتيونات شيوعا فى مستخلص عجينة التربة المشبعة ، يليها كانتونات الكالسيوم ثم المغنسيوم

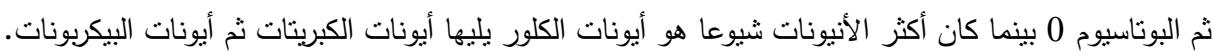

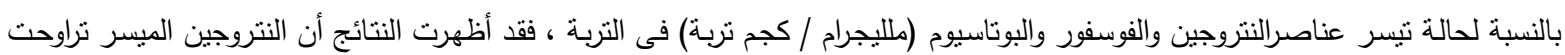

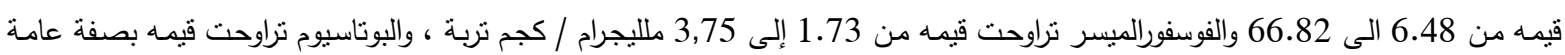

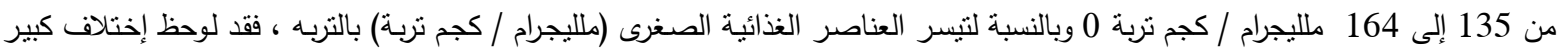
في قيمها فيمـا بين المواقع تحت الدراسـة ، وبصـفة عامـة نرواحت القيم الميسرة (ملليجرام / كجم تربـه) لعنصـر الحديد (1,01 - 14,14) والمنجنيز (2,05 - 2,99) والزنك ( 0,03 - 1,61) 0 وبالنسبة لعنصر النحاس وتيسره فى التربه فقد سجل قيم تجاوزت الحدود الحرجة أو المسموح بها (5,29) (5) (5)

\section{• ويالنسبة لمحتوى العناصر المغذية لبعض المحاصيل المنزرعة} بالنسبة لمحتوى محاصيل من النتروجين والفوسفور فقد نرواح محتواها مابين 2.79الى 5.11 \% للنتروجين و 0.33 الى 0.55 \% للفوسفور و 1.87 الى 4.92 \% للبوتاسيوم. 4.92 وبالنسبة للعناصر الصغرى فقد إختلف محتواها من الحديد والزنك والمنجنيز من نوع لأخر ـ وقد تجاوز محتوى كل المحاصيل تحت الدراسة من عنصر النحاس الحدود المسموح بها ووصلت لحدود السمية. 